subsidies towards the expenses of research work to those qualified to undertake it. As stated at the time the qualifications of the candidate, the proposed subject for research and the place where it is to be undertaken, must be submitted for approval to the Editorial Committee. The applicant should give an estimate of the time and expense necessary for the completion of the research and indicate the extent of the financial assistance required.

The right to publish papers based on the research must be given to this journal. Applications on this subject should be addressed to the Editors.

\title{
THE COUNCIL OF BRITISH OPHTHALMOLOGISTS
}

\section{Annual Report}

The Council presents its report for the year 1934-35. At its first meeting the following were elected as Officers :-President : Mr. Leslie Paton; Vice-Presidents: Mr. P. H. Adams, Mr. E. Brewerton; Hon. Treasurer: Mr. A. H. Levy; Hon. Secretary : Mr. M. L. Hepburn.

The following were appointed to serve on the Executive Committee :- The President and Secretary (ex-officio) with Messrs. Greeves, Juler, Levy, Neame, Russ-Wood, and Miss Ida Mann. $\mathrm{Mr}$. Juler and $\mathrm{Mr}$. Neame were elected to represent the Council on the Ophthalmic Committee of the British Medical Association.

It is with much regret that the Council has to report the resignation of $\mathrm{Mr}$. Leslie Paton, who felt compelled to give up his position as President. The Council wish to express their sincere thanks for his efforts and guidance during his term of office. Sir John Parsons was unanimously elected President to succeed him.

The Council has to deplore the death of two of their most active members :- Mr. Bernard Cridland and Mr. Stephen Mayou. The latter was the Treasurer to the Council at the time of his death, and did very valuable work on various Sub-Committees connected with many subjects. He also was one of the Council's representatives on the Ophthalmic Committee of the British Medical Association, and his services helped to keep the two bodies closely in touch with each other. Mr. Bernard Cridland's special experience in the industrial diseases of the eye led the Council to entrust to him much work in any investigations on such subjects : and he always gave of his best ungrudgingly in the service of the Council.

During the year the Council has been investigating the question of Orthoptic Training and the status of those who practise or 
wish to qualify for practice in this branch of ophthalmology. A sub-committee has been appointed to consider the whole subject, and have already presented three reports which the Council are engaged in considering.

The Council have also had their attention drawn to the fact that the Hospital Savings Association has been encouraging their members to seek the advice of sight testing opticians ; and representatives of the Council together with those of the Ophthalmic Committee of the British Medical Association waited on the Hospital Savings Association Council at their offices and placed their case before them. The interview did not lead to any practical results, and both the Council and the British Medical Association are debating what further steps should be taken in the matter.

The expenses of the Council have, as usual, been defrayed by contributions from its members.

\section{INTERNATIONAL ORGANIZATION OF THE CAMPAIGN AGAINST TRACHOMA AND INTERNATIONAL ASSOCIATION FOR PREVENTION OF BLINDNESS}

On the occasion of the Annual Congress the Council of the Ophthalmological Society invited the International Organization of the Campaign against Trachoma and the International Association for the Prevention of Blindness to hold their annual meetings in London. The invitation was gratefully accepted by the sister societies, offspring of the International Council of Ophthalmology.

The International Organization of the Campaign against Trachoma held its first meeting on April 3 when Professor de Grosz (Hungary) announced his resignation of the office of President. He has filled the post most admirably since the foundation of the Organization in 1929. He has been succeeded as President by Mr. A. F. MacCallan (Great Britain), while Dr. F. Wibaut (Holland) remains as Secretary-General.

At the scientific meeting on April 3 the subject for discussion was "The social and legal measures to be taken against trachoma." After an introductory paper read by Mr. MacCallan*, reports of very great interest were read by Dr. Josephus Jitta (League of Nations), Dr. Tewfik (Egypt), Professor Miyashita (Japan), and Dr. Zachert (Poland).

\footnotetext{
* Published in May No.
} 